\title{
FINANCIAL REPORTING STANDARD OF NIGERIA AND UNITED STATE OF AMERICA: THE IMPLICATION FOR ADOPTION AND PRACTICE OF INTERNATIONAL FINANCIAL REPORTING STANDARD
}

\author{
Ajibade, Ayodeji ${ }^{\mathrm{a}}$, Fatoke Adedeji ${ }^{\mathrm{b}}$, Ogundeyi, Adebayo ${ }^{\mathrm{c}}, \mathrm{Ojo}$ Dada $^{\mathrm{d}}$, Dennis Gogo Cookey ${ }^{\mathrm{e}}$ \\ ajibadea@babcock.edu.ng \\ ${ }^{a}$ Department of Accounting, Babcock University, Nigeria \\ batokea@babcock.edu.ng \\ ${ }^{b}$ Department of Accounting, Babcock University, Nigeria \\ cbayoogundeyi@yahoo.com \\ ${ }^{c}$ Department of Accounting, Babcock University, Nigeria \\ dojod@babcock.edu.ng \\ ${ }^{d}$ Department of Accounting, Babcock University, Nigeria \\ edennis.cookey@firs.gov.ng \\ ${ }^{e}$ Department of Accounting, Babcock University, Nigeria
}

\begin{abstract}
To actualise accounting strategies regarding the way wherein the everyday money related exercises of a business substance are assembled, recorded and announced has encountered extensive advancement on the planet everywhere. In the meantime, the exercises of worldwide ventures and speculator conduct remain the point of convergence in the discussion on the requirement for a worldwide arrangement of accounting standards. This paper recognized the contrasts between Nigerian GAAP and US GAAP comparative with IFRS using a subjective methodology involving the investigation and examination of a wide scope of talks, the assessment of a writing survey from distributions, understudies papers, web sources, administrative-accounting bodies, and gathering procedures. It was revealed that the distinctions concerning the introduction of the money related instruments gave by an auxiliary in the parent's united fiscal reports could drive generously various outcomes. Along these lines, the study recommends that administrative bodies should uphold IFRS standards profoundly, looking for the neighbourhood content where important while giving convergence as opposed to adoption.
\end{abstract}

Keywords: Accounting Standards; Convergence; IFRS' Adoption practice; Generally Accepted Accounting Principle.

\section{INTRODUCTION}

Digitalisation has certainly made a major contribution to globalization and made worldwide enterprises access to the public, especially through the outside stock and obligation markets. Klug (2009) has shown that the actions of speculators and the exercise of worldwide ventures represent the guiding force behind the debate on the need for a global set of accounting standards. The basic accounting strategy for the collection, recording, and disclosure of the daily exercises of a company substance has therefore enjoyed considerable progress on the planet. Ehiagwina et al. (2017), on the other hand, generally saw the autonomous creation of accounting, announcement and the procedure, guideline and, of course, the mode as the number of guidelines always shifts from nation to nation Aifuwa et al., ( 2018) believed that business development towards a worldwide economy, monetary detailing and its final results (fiscal reports) to disperse financial reports. Hence, the use of budget summaries completely distinguishes global accounting from local accounting.

Identifying that the arrangements for fiscal summaries under several nation's accounting principles were often not identical (Ocansey and Enahoro, 2014), Ehiagwina et al. (2017) argued that the concept of global accounting is becoming important where accounting reports are used by assorted clients in different countries. Widely varying clients in various nations likewise affect the development of their accounting principles and laws. This may be because of the degree of swelling, size and multifaceted nature of relationships in the country in which the accounting system operates (Ehiagwina et al., 2017) because accounting enhancement is deeply an aspect of outer money, the legal framework, political and financial ties with different nations. Furthermore, Aifuwa et al. (2018) 
showed that the variety of money-related information can be estimated in terms of their highlights, such as the importance, unwavering depiction, understandability, equivalence, and ideality of budget papers.

Besides, Klug (2009) recognized the worldwide variety of accounting standards among a few variables that allow communication at the universal level in the understanding and investigation of fiscal reports. For instance, Ocansey and Enahoro (2014) reiterated that because one organization reports under Ghanaian accounting standards (NNAS) and another report under the United States General Accepted Accounting Principle (U.S. GAAP) accounting standards of the United States, a speculator would not have the option of structuring the two without changing different accounting sections. In this regard, the comparison becomes problematic and meaningless without alterations. The structure of global accounting primarily implies accounting in different kinds of circumstances. Beuren and Klann (2010) are of the view that to decrease or even dispose of the asymmetry of data confirmed in reports delivered, the requirements of different nations is one of the difficulties looked at by administrative-accounting offices overall.

Strengthening the previous, Ocansey and Enahoro (2014) stated that before the International Financial Reporting Standards (IFRS) declaration, different nations developed their national accounting standards or received that of different nations. In Nigeria, for example, the organizations and partnered matters Act outlines the direction framework for budgetary accounting and disclosing by enlisted organizations and defines the essential most stringent requirements regarding monetary detailing. As a consequence of the limited details found in the Act in compliance with Micah et al. (2012), the Nigerian Accounting Standard Board (NASB) complements currency announcements and guidelines. Statement of Accounting Standards (SAS) was the standards developed and established by NASB. The International Accounting Principles (IAS) was modified in SAS. In either case, NASB has again been named as Financial Reporting Council of Nigeria (FRCN). The FRCN was established to replace the previous Nigerian Accounting Standards Board (NASB) by the Financial Reporting Council of Nigeria Act, 2011.

The FRCN has the legal capacity to create the 'open intrigue' budget requirements, which include not only cited and unquoted organizations but also states, governmental associations or non-revenue-related substances that are legally required to record (Shiyanbola et al., 2015). The Federal Executive Council (FEC) announced in 2010, that Nigeria would adapt to International financial reporting standards (IFRS) but NASB changed to Financial Reporting Council in 2011 to the Ministry of Business, Trade and Investment in 2011. In response to the Federal Ministry of Industry, Trade and Investment, Nigeria is currently one of the countries with IFRS to including over 120 countries that have implemented the International Funding Reporting Requirements; there seem to have been two dependent accounting norms in the globe at that moment; the US GAAP and IASB IFRS GAAP (Isaqpa and Obayemu, 2018).

Numerous worldwide offices such as the International Accounting Standards Board ( IASB), the International Federation of Accountants (IFAC), the United Nations Conference on Trade and Development (UNCTAD) and the International Organization of Securities Commission (IOSCO) have sought to advance the integration of various neighbouring standards into new ones with the ultimate goal of growing high standardized accounting practice.

The IFRS is viewed by the International Accounting Standards Board (IASB) as a global GAAP and a set of principles-based and comprehensively agreed on standards to assist individuals involved in the preparation of fiscal summaries to obtain ready and current consistency, transparent and virtually equivalent budget reports around the world (IFRS Foundation; 2017; Abata, 2015). In contrast to the standard-based GAAP approach, Akhidime and Ekiomado (2014) described IFRS as a single arrangement of principle-based justifiable and topnotch criteria for widely useful money-related disclosure. IFRSs are intended to pacify over-dependence and energize proficient judgment on certain guidelines (Akhidime and Ekiomado, 2014).

Since its introduction in 1973, the integration of International Financial Reporting Standards (Needles, 2010) into the financial reporting system has seen a substantial rise, and over 100 countries around the world have either adopted or plan to adopt IFRSs (Belesti and Kerima (2019) for financial reporting purposes for their domestic companies. Shiyanbola et al. 2015). Tohmatu (2007) argued that around the world, IFRS is gaining significant 
approval. It allows U.S. businesses to examine the possible consequences of implementing the standard, and it was proposed in 2011 that IFRS could be used to a degree by almost any country around the world, including the United States. Eke (2018) clarified that IFRS was issued by the International Accounting Standards Board (IASB) to satisfy the financial reporting requirements of different users of cross-border financial statements. According to the author, the objectives of IFRS include:

i. serving as a global set of accounting standards to be adopted by preparers of financial statements of private sector entities.

ii. ensuring comparability, accountability and transparency in financial reporting by private sector entities.

iii. advancing the quality of general purpose financial reporting by private sector entities.

iv. enhancing the disclosure of financial information by private sector entities.

v. ensuring consistency in the preparation and reporting of financial information.

vi. certifying the efficient provision of capital globally thereby attracting investment through transparency, reducing the cost of capital and increasing worldwide investment.

vii. reducing costs and increasing efficiency in financial reporting and as such facilitate calibration of information systems, enhance audit efficiencies and facilitate the training of preparers of financial statements.

However, despite the intention of IFRS to ensure continuity in the financial accounting reporting system across countries around the world, complete implementation of IFRS in the United States continues to face long odds (Tysiac, 2016), although many U.S. businesses, especially those with global operations, are interested in IFRS efficiency. The U.S., being the world's largest stock market, is also hesitant to completely integrate IFRS into its financial reporting scheme, according to Bogopolsky (2015), despite the acceptance of IFRS on all continents over the past ten years.

Therefore, concerning how and to what degree they integrate IFRS into their financial reporting scheme, this paper described the divergences between Nigeria and the United States.

\section{METHODOLOGY}

By researching and reviewing a wide variety of discourses, evaluating a literature review from journals, student papers, internet outlets, regulatory accounting bodies and conference proceedings, opinion articles and textbooks, the research adopted a qualitative approach.

\subsection{IFRS adoption in the U.S. and Nigeria}

Oseni (2013) outlined various methodologies, commonly known as Generally Accepted Accounting Principles (GAAP), have been observed in the preparation of financial reports. In the financial proclamations, GAAP gave direction and foundations for recording exchanges. In the past, various countries around the world have established their accounting standards by applying widely accepted accounting principles. Standards, also known as GAAP, established in a particular nation to use the arrangement of financial articulations were referred to as nearby accounting standards (Eke, 2018). GAAP was confined to domestic situations, leading to the invariance of the parent organizations ' financial data in many countries, including Nigeria (Oseni, 2013).

The Statement of Accounting Standards (SAS) arranged by the Nigerian Accounting Standards Board (NASB) was the Local Accounting Standards on which the structure of financial articulations was based in Nigeria, as indicated by Ofoegbu and Odoemelam (2018). The GAAP section complies with IAS (Ofoegbu and Odoemelam 2018). However, the number of neighbourhood standards did not precisely correspond to the quantity of IAS without corresponding to the need for IFRS. Furthermore, Impey (2017) noted that the nearby standard has become outdated and insufficient to form a reason for excellent financial explanations to enhance Nigeria's report's significance in the world market. In 2010 the Federal Government, therefore, laid down a bill before the National Assembly creating the Nigerian Financial Reporting Council to support the adoption of IFRS in Nigeria. Although Abata (2015) has shown that IFRS effects in total the financial detail practice in Nigeria, the IFRS also provides more important financial clarification advantages than the previous SAS, cross-border postings, fusion and acquisitions and transparency. Thus, IFRS adoption and use were expected to influence organizational presentation and the enhancement of agreed organizational procedures, while increasing the level of compliance with accounting standard. Although Tysiac (2016) has observed that while complete IFRS adoption in the USA continues to be one in a million chances, understanding IFRS remains important for US speculators. In September 2002, therefore, the IASB and the FASB agreed in a Memorandum of Understanding (MoU) between the Norwalk Agreement (IFRS Foundation, 2017) to cooperate with counsel to other national and local institutions to evict the contrasts of IFRS standards and US GAAP. 
The focus of the two Boards, as suggested by Tohmatsu (2007), was to make their current financial announcement standards entirely good when it is possible and to figure out their potential work projects to ensure that the similarity is preserved once achieved. In either case, similarity does not imply indistinguishable norms in precisely the same terms but instead means that there are no critical contrasts between the two standard arrangements. In any event, there has been significant controversy about the contrasts between the U.S. GAAP accounting criteria for rules-based and IFRS methodologies based on principles (Edwin, 2014).

Aside from the fact that the United States GAAP encourages bookkeepers to secure IFRS data, as a result of this, the U.S., in 2011 did not change IFRS because of its increasingly abstract principle-based way of thinking, GAAP worries that IFRS might add to accounting impropriety issues. This is a deviation from the chronicled cost principle and the chance to underwrite versus cost certain things (Harris, 2013; Edwin, 2014). For instance, Bogopolsky (2015) argued that there is a new specialized contrast between the IASB and FASB, alongside the "old" ones, and those not killed over the period of past convergence, continue to create and develop several separate specialized directions, which obviously does not promote the process of convergence or even harmonization of US GAAP and IFRS from a simply specialized approach. He also showed that one possible purpose behind the lack of progress in convergence is the political and non-specialized accounting zone. What's more, it is accepted that financial articulations arranged under U.S. GAAP are clear, solid, can without much of a stretch be contrasted and the GAAP financial explanations of different organizations, and can be evaluated and confirmed by an autonomous outsider examiner as per built up to standards (Hamilton 2013). Moreover, it is understood that financial articulations structured under the U.S. GAAP are straightforward, strong, can be contrasted without much of a stretch and various organizations' GAAP financial explanations can be tested and verified by an autonomous outsider examiner as built up to expectations (Hamilton 2013).

In either case, Tysiac (2016) stated that IFRS data and perception, including similarities and contrasts between the U.S. As the interconnectedness of the worldwide commercial centre, has made a prerequisite for IFRS familiarity with the United States, GAAP and IFRS are highly important to partners reviewing exchanges and associated financial information commitments. My suggestion, Nigeria's complete adoption and use of the worldwide GAAP (IFRS) are likely to demonstrate major contrasts in the readiness and introduction of financial reports between U.S. company components. The objective of this study was to make sense of a portion of the major distinctions that are usually found in practice between the entire Nigerian adoption of IFRSs and US GAAP. The crucial contrast between Nigeria and the United States in the degree of IFRS acceptance and implementation can be presented in the accompanying regions.

\subsection{Status of IFRS adoption}

In Nigeria, IFRS Standards are needed for the financial proclamations of all 'open intrigue elements', which include cited and unquoted organizations as well as states, government associations, and the not-revenue driven elements that are legally appropriate to record comes back with administrative specialists. Under the U.S., the SEC does not, however, require foreign private backers to apply IFRS requirements as set out by the International Accounting Standards Board in the establishment of the guarantor's financial statements. Similarly, the SEC does not authorize its household guarantors to use IFRS criteria to provide financial explanations. Or maybe they are supposed to use the US GAAP (IFRS Foundation, 2016 and 2017).

\subsection{Extent of Application}

In Nigeria, in their consolidated financial statements, all domestic and foreign companies with securities trading in the public market must use IFRS standards. This involves all the organizations exchanging on the mainboard and the Nigerian Stock Exchange Alternative Securities Market (ASeM). Although the financial announcement structure for the use of organizations whose exercises on the capital market are outside the borders of the SEC under the U.S. GAAP is not incorporated into this document. Any remote organization with open market protectors can use IFRS Standards in their sound financial statements (IFRS Foundation 2016 and 2017).

\subsection{Auditor's Report}

Dual reporting does not allow in Nigeria, as well as the basis for the Auditing Notice, double reporting is available in the United States, whereas the Auditing Report and the basis for the preparation of footnote. If in addition to the enforcement with the IFRS requirements as published by the Board, the financial statements are not in compliance with a qualified GAAP, then the financial statements can also be complied with by the jurisdictional 
GAAP. In this event, the auditor also expressed his views on compliance with the GAAP jurisdiction in the financial statements (IFRS Foundation 2016 \& 2017).

\subsection{IFRS Standards incorporation into law or regulations}

While Nigeria has incorporated IFRS standards into laws or regulations and the FRC has the legislative authority to issue accounting standards, IFRS standards and the IFRS Standard for SMEs have been adopted by the FRC. On the contrary, IFRS standards have not been adopted by the United States into laws or regulations. Although the 'IFRS as provided by the IASB' body of standards is invoked under the SEC regulations for the reporting by international private issuers, either the federal securities laws or the SEC rules and regulations (IFRS Foundation, 2016 \& 2017) do not contain the text of IFRS standards.

\subsection{Inventory Costing}

Inventory costs are typically calculated under IFRS by using the first-in, first-out (FIFO) or weighted average cost process. It is forbidden to use last-in, first-out (LIFO). Companies have the option between Last in, first out and first-in, first-out expense approaches under the U.S. GAAP. Like IFRS, FIFO or weighted average approach is used to calculate costs while under Nigerian GAAP LIFO is prohibited (Adekoya, 2011, Price water house Coopers, 2019).

\subsection{Consolidated Financial Statement}

Under IFRS, all entities it controls, including those controlled by a subsidiary investment company, are consolidated by the parent of an investment company, which must be an investment company. A parent of an investment company is required, unlike IFRS, to retain the fair value accounting of the investment company subsidiary in the consolidated financial statements of the parent under the US GAAP. Under Nigerian GAAP, the holding company owns most of the equity capital but less than half of the voting stock (Adekoya, 2011, Price water house Coopers, 2019).

\subsection{Historical Cost or Fair Value}

Under IFRS, the principal accounting convention is the historical expense. Nonetheless, IFRS makes the revaluation of impalpable properties, land, plant, and machinery (PPE), the property of speculation, and inventories in particular enterprises. IFRS also allows that particular groups of financial instruments and certain natural resources be calculated to be accurately estimated (Drake and Fabozzi, 2010). US GAAP typically uses verifiable costs and, apart from unique classifications of financial instruments expressed at a fair value, avoids revaluations. With some distinctions, Nigerian GAAP is like IFRS, but with fewer takeoffs from reported expenses.Instead of gain or misfortune, revaluation additions or misfrtunes on a speculative property are taken $t$ $o$ value. Financial instruments are regularly conveyed at cost or amortized cost and exposed to arrangements for misfortunes in esteem (Adekoya, 2011, Pricewaterhouse Coopers, 2019)

\subsection{Investment Property}

Investment property is separately classified under IFRS as property (land and/or buildings) owned to earn leases and/or capital appreciation. The meaning excludes property involved by the proprietor, which is property kept available for purchase in the traditional business course (Wiley, 2019), or property constructed or created for such an arrangement. Properties under construction or development for later use as venture properties are within the domain of property speculation. There is no clear definition of a speculative property under US GAAP. For most land organisations and working organizations holding venture style lands, the authentic cost model is used. IFRS venture property is implemented separately or as a major component of fixed capital or long-term speculation under Nigeria GAAP (GAAP IAS 2 and ASC 330, Adekoya, 2011, Price Water House Coopers, 2019).

\subsection{Recognition and Derecognition}

An organization accepts item that in the financial statements and identifies an asset or a liability unless it affects the importance or faithful representation of the information provided: its 'significance' may be impaired if there is vagueness regarding the existence of a benefit, obligation or the likelihood of an inflow or outflow of monetary 
benefits from the benefit or obligation. Under US GAAP, the recognition rules apply to an item that as of now passes the limit of 'plausible revenue,' which is a piece of the sense of advantage or duty, not at all like IFRS standards. Subject to a money-saving advantage requirement and materiality edge, an element perceives the thing in the financial articulations, even if the thing or data about it is not quantifiable, important, or solid (KPMG International Standards Community, 2020).

That being said, when it no longer meets the sense of advantage or duty, a thing is derecognized from the financial articulations under IFRS. This is followed by a correct presentation and disclosure. Under US GAAP, there is no clear derecognition path in the Conceptual Context, not at all close to IFRS norms. Instead, the derecognition of substantial assets and liabilities that might differ from IFRS standards (KPMG International Standards Community, 2020) is managed through explicit codification themes.

\subsection{The basis for the preparation of financial statements}

The reason for the preparation of financial proclamations under IFRS is determined by the assessment of the going concern. The assessment of going concerned for one year from the financial articulations provided (accessible for the issue) is not at all like IFRS standards. This assessment is to determine whether the exposures in the financial articulations are appropriate. Also, the purpose of preparing financial explanations is not affected even if liquidation is approaching. There is no broad control of their assessment, identification, and disclosure needs on the off chance that the element is certifiably not a going concern and the financial articulations are being defined according to IFRS standards. If liquidation is up and coming, there are clear prerequisites for calculating, identifying, and reporting under US GAAP (KPMG, 2020), not at all like IFRS norms.

\subsection{Form and components of financial statements}

Unless specific requirements are met, a company with one or more subsidiaries presents consolidated financial statements. Unlike the IFRS Requirements, if an organization has one or more branches, there are no exemptions other than for investment firms from the preparation of consolidated financial statements. Comparative information is only needed for the previous time, although it is possible to present additional periods and information. US GAAP does not need comparative details to be provided (KPMG International Standards Association, 2020), unlike IFRS Standards.

\subsection{Statement of Cash Flows}

To identify each of its interest and dividends to be paid as operational or funding operations, an organization chooses its policy. It also determines whether to earn interest and dividends as an operating or investment operation. In comparison to IFRS requirements, interest earned and charged (net of capitalized interest) as well as dividends received from previously undistributed earnings must be listed as operating activities. Besides, dividends paid are expected to be listed as supporting operations, unlike IFRS standards (KPMG International Standards Community, 2020).

\subsection{Consolidation}

Consolidation is based on what can be considered a paradigm of 'power-to-direct'. An investor 'controls' as an investor is exposed to variable returns through its interaction with the investor and, through its advantage over the investor, may influence those returns. This control model applies to both, but there is a working difference between structured and non-structured entities. The Consolidation is governed by financial interest model, unlike IFRS Standards, which varies from IFRS Standards in some respects (KPMG International Standards Community, 2020).

\section{CONCLUSION AND RECOMMENDATIONS}

The advantages of IFRS in ensuring comparability, accountability, transparency, and continuity in financial reporting practice across the world cannot be over-stretched. However, a close review of the debate on financial reporting standards in Nigeria and the U.S. revealed that the implementation and practice of IFRS disagreed between the two countries. Essentially extraordinary work results such as an increase in revenue can be achieved by organizations that use the LIFO costing philosophy under the US GAAP. While under Nigerian GAAP and paying little attention to the stock costing model used, organizations are confronted with higher income uncertainty comparable to recuperations in values recently recorded. On the contrary, the application of the 
financial instruments supported by an auxiliary in the united financial articulations of the parent will lead to drastically different results.

In the same vein, to revalue resources for (reasonable worth) under Nigeria GAAP, a contrast expressing the estimation of benefits as the contrasting need to be shown between the US GAAP. It is therefore suggested that the U.S. and Nigeria need to organize their financial detailing practices to understand the importance of the adoption of IFRS. Likewise, administrative bodies should screen and empower IFRS standards as needs by looking for the neighbourhood content where necessary and giving convergence instead of adoption. 


\section{REFERENCES}

Abata, M.A. (2015). Impact of IFRS on Financial Reporting Practices in Nigeria (A case of KPMG). Global Journal of Contemporary Research in Accounting, Auditing and Business Ethics (GJCRA), 1(1), 264281

Adekoya, O. (2011). Similarities and differences, IFRS and Nigerian GAAP. Lagos: Price water House Coopers International Limited. (PWCIL).

Aifuwa, H. O., Embele, K., \& Saidu, M. (2018). Ethical accounting practices and financial reporting quality. EPRA Journal of Multidisciplinary Research, 4(12), 31-44.

Akhidime, A. E., \& Ekiomado, E. B. (2014). Adoption and Implementation of International Financial Reporting Standards (IFRSs) In Nigeria: Enduring Challenges and Implications. International Journal of Development and Sustainability, 3(11), 2090-2100.

Belesti, W. \& Kerima, R. (2019).Factor analysis on IFRS Adoption: A survey study on lenders, users and audit firms' perspective in West Hararghe Zone, Oromia Regional State, Ethiopia. Journal of Accounting and Taxation, 11(9), 178-189

Beuren, I.M. \& Klann, R. C. (2010). Divergences between the BR GAAP and US GAAP. Journal of Accounting and Taxation, 2(2), 031-041

Bogopolsky, A. (2015). Does IFRS Have a Future in the US? International Federation of Accountants.

Drake, P. P., \& Fabozzi, F. J. (2010). The Basics of Finance: An Introduction to Financial Markets, Business Finance, and Portfolio Management (Vol. 192). John Wiley \& Sons.

Edwin, Q. (2014).The Challenges for Establishing the Convergence of Accounting Reporting among Different Countries. International Journal of Academic Research in Accounting, Finance and Management Sciences, 4(2), 144-151

Ehiagwina, A.I., Idrisu,I.D. \& Aturu-Aghedo, C. (2017). International accounting system. Ent432.National Open University of Nigeria (Noun)

Eke, G.O. (2018). Adoption of international financial reporting standards in Nigeria: a conceptual appraisal. European Journal of Accounting, Auditing and Finance Research, 6(9),8-22

Hamilton, J. (2013). FASB chair says U.S. GAAP is here to stay. New York: CCH Incorporated: Health \& Human Resources.

Harris, P. (2013). U.S. GAAP conversion to IFRS: a comprehensive case study. Internal Auditing, 28(3), $31-41$.

IFRS Foundation. (2016). IFRS application around the world, jurisdictional profile: Nigeria. https://cdn.ifrs.org//media/feature/around-the-world/jurisdiction-profiles/nigeria-ifrs-profile.pdf

IFRS Foundation. (2017). IFRS application around the world, jurisdictional profile: United States of America. https://www.ifrs.org/-/media/feature/around-the-world/jurisdiction-profiles/united-states-ifrsprofile.pdf

Impey, A. (2017). Understanding IFRS. https://www.pwc.com/ng/en/publications/understanding- ifrs.htm

Isakpa and Obajemu, (2018). Nigeria has done fairly well on IFRS, but IFRS 9 is game changer for balance sheets of banks. https://www.businessamlive.com/nigeria-has- done-fairly-well-on-ifrs-but-ifrs-9-is-gamechanger-for-balance-sheets-of-banks/

Klug, C. (2009). International accounting differences- Will national differences still play a role in the future? Unpublished Master Thesis, Karlstads University.

KPMG International Standards Group (2020). IFRS compared to US GAAP https://frv.kpmg.us/referencelibrary/2020/ifrs-compared-to-us-gaap.html 
Micah, L. C., Ofurum, C. O., \& Ihendinihu, J. U. (2012). Firm's financial performance and human resource accounting disclosure in Nigeria. International Journal of Business and Management, 7(14), 67 - 75

Needles Jr, B. E. (2010). Accounting education: The impact of globalization. Accounting Education: an International Journal, 19(6), 601-605.

Ocansey, E. O., \& Enahoro, J. A. (2014). Comparative study of the international financial reporting standard implementation in Ghana and Nigeria. European Scientific Journal, 10 (13), 529 -546

Ofoegbu, N. G., \& Odoemelam, N. (2018). International financial reporting standards (IFRS) disclosure and performance of Nigeria listed companies. Cogent Business \& Management, 5(1), 1542967. Oseni, M. (2013). Application and challenges of International financial Reporting standards in Nigeria. Oman Chapter of Arabian Journal of Business and Management Review, 34(983), 1-8.

PricewaterhouseCoopers, L. L. P. (2019). IFRS and US GAAP: Similarities and differences. https://www.pwc.com/us/en/cfodirect/assets/pdf/accounting-guides/pwc-ifrs-us-gaapsimilarities-and-differences.pdf.

Shiyanbola, A. A., Adeyemi, S. B., \& Adelakun, O. J. (2015). Issues and challenges in the adoption of International Financial Reporting Standards in Nigeria. Journal of Research in National Development, 13(1), 176-187.

Tohmatsu, D. T. (2007). IFRSs and US GAAP: A pocket comparison. An IAS Plus guide. https://www.iasplus.com/en/binary/dttpubs/0809ifrsusgaap.pdf

Tysiac, K. (2016). Why IFRS remains relevant in the U.S. Journal of Accountancy.

Wiley, I. F. R. S. (2019). Interpretation and Application of IFRS Standards. PKF International Ltd. 